\title{
The Inbreeding Case of Bali Cattle (Bos javanicus) at Breeding Station
}

\author{
Widya Pintaka Bayu PUTRA ${ }^{*}$, Muzawar MUZAWAR ${ }^{2}$ \\ ${ }^{1}$ Indonesian Institute of Science, 16911, Bogor, West Java, Indonesia \\ ${ }^{2}$ Bureau of Artificial Insemination (BAI) of Lelede, 83362, Mataram Indonesia
}

\begin{abstract}
Highly inbreeding level in the livestock had negative effect to productivity traits. This study was carried out to report first inbreeding case of Bali cattle (Bos javanicus) based on the records data from year 2013 to 2018 at breeding center of Indonesia. Two inbred calves (ID: 0991 and 0812) were born from the inbreeding mating between paternal halfsib parental (ID: 0874 and 0881). One inbred calf (ID: 0812) was dead one day after birth. The inbreeding coefficient $\left(\mathrm{F}_{\mathrm{x}}\right)$ in both inbred calves were 0.125. It was seen that birth and adult performances in the inbred cattle were lower than their parents. It can be concluded that the level inbreeding $12.5 \%$ in Bali cattle had negative effect of low performance and calf's dead case.
\end{abstract}

Keywords: Bali cattle, Inbreeding coefficient, Inbred calves, Breeding center

\section{Bali Damızlık Sığır (Bos javanicus) Sürülerinde Akrabalık Durumu}

\section{ÖZ}

Akrabalı yetiştirme çiftlik hayvanlanında verim özellikleri üzerinde olumsuz etkilere sahiptir. Bu çalışmada Endonezyada yetiştirme merkezinde (çiftliğindeki) yetiştirilen Bali (Bos javanıcus) sığırlarının akrabalık durumu 2013 - 2018 yılları arasındaki kayıtlara dayalı olarak ortaya konmuştur. Üvey kardeş ebeveynlerin (ID: 0874 ve 0881) birleşmesinden 2 akrabalı yetişmiş buzağı (ID: 0991 ve 0812) elde edilmiştir. Böylece bir akrabalı yetişmiş̧ buzağ1 (ID: 0812) doğumdan bir gün sonra öldü. Böylece akrabalı yetişme katsayıs1 $\left(\mathrm{F}_{\mathrm{x}}\right)$ her iki buzağıda da 0.125. Genel olarak akrabalı yetişmiş sığırların doğumda ve ergin yaştaki performansı ebeveynlerinden düşük olmaktadır.

Anahtar Kelimeler: Bali sığır, Akrabalı yetiştirme katsayısı, Akrabalı yetişmiş buzağı, Yetiştirme merkezi

To cite this article: Putra W.P.B. Murawar. The Inbreeding Case of Bali Cattle (Bos javanicus) at Breeding Station. Kocatepe Vet J. (2020) 13(4):439-442 


\section{INTRODUCTION}

The inbreeding commonly had negative effect to productive traits in livestock. Moreover, the inbreeding in the less number of animals population can be caused extinction (Julian et al. 2006; Theodorou and Couvet, 2006). However, many farm industries were managed the inbreeding to collect the desirable allele (gene). The inbreeding of livestock can be controled through inbreeding coefficient $\left(F_{x}\right)$ value (Laws and Jamieson 2011). Alvarez et al. (2011) stated that the $F_{x}$ value more than 0.30 can be increased the risk of mortality and disorder in offspring.

Bali cattle (Bos javanicus) are the one of Indonesian native cattle that originated from Bali island and was spread in other islands of Indonesia. Thus, two genetic markers in mtDNA of Bali cattle i.e. D-loop and Cytochrome Oxidase Sub unit 1 (COI) were similar to wild Banteng that spread in Southeast Asia (Wisesa et al. 2012; Wulandari et al. 2019). Bali cattle were declared as the Indonesian native cattle since year 2010 through decision of Indonesian Ministry of Agriculture No: 325/Kpts/OT.140/1/2010. Kaswati et al. (2013) reported that the average of weaning weight (205 days of age) and yearling weight (365 days of age) in Bali cattle at the breeding station (Bali Island) were $88.59 \pm 16.15 \mathrm{~kg}$ and $131.12 \pm 25.50 \mathrm{~kg}$ respectively. In addition, Priyanto et al. (2019) reported that the average of slaughter weight, carcass weight and dressing percentage in Bali cattle were $275.56 \pm 61.93 \mathrm{~kg}, 141.04 \pm 35.61 \mathrm{~kg}$ and $50.95 \pm 3.49 \%$ respectively.

The genetic improvement for Bali cattle can be conducted based on selection program. Thus, mostly the selection program of Bali cattle in Indonesia was performed with conventional method. The conventional selection to improve the productive traits can be performed through data and pedigree records of livestock. Despite, the data record is important to reduce the inbreeding risk in livestock. This study was aimed to report and evaluate the first inbreeding case in Bali cattle at Bureau of Artificial Insemination at Lelede (BAI Lelede), Indonesia. The results study is important for BAI Lelede to applied good breeding practices mainly in recording and mating systems in the future.

\section{CASE HISTORY}

The breeding program of Bali cattle at BAI Lelede was started at year 2013. The artificial insemination (AI) and natural mating (NM) methods were used in this breeding station. A Bali cow with service per conception (S/C) more than three will be mated with NM method. Bull ID: 0874 and cow ID: 0881 were born from AI method with similar sire (Straw ID: 11012/003) and different dam as presented in Figure 1. According to the herd records, both cattle were mated with NM method and had two calves. First calf (male) was born at 2017 with ID: 0812. Meanwhile, the second calf (female) was born at 2018 with ID: 0991. Unfortunately, calf ID: 0812 was dead one day after birth. Meanwhile, calf ID: 0991 still survive until in the present study (Figure 2). According to the data records, the birth performance (birth weight, heart girth, withers height and body length) in both calves were lower than those detected in both parents as presented in Table 1. In addition, the adult performance of cow ID: 0991 was lower than both parents as presented in Table 2. According to the farm manager, the inbreeding case in BAI Lelede was caused by human error, mainly in the breeding bull rotation controlling.

Table 1. The birth performance of inbred calves family at BAI Lelede

\begin{tabular}{clccccccc}
\hline \multirow{2}{*}{ Cattle ID } & \multirow{2}{*}{ Sex } & \multirow{2}{*}{ Sire } & \multirow{2}{*}{ Dam } & \multirow{2}{*}{$\begin{array}{c}\text { Date of } \\
\text { birth }\end{array}$} & \multicolumn{4}{c}{ Birth performances } \\
\cline { 6 - 9 } & & & & BW (kg) & HG (cm) & WH (cm) & BL (cm) \\
\hline $\mathbf{0 8 8 1}$ & Female & $11012 / 003$ & 01179 & $15 / 07 / 2014$ & 16 & 58 & 63 & 60 \\
$\mathbf{0 8 7 4}$ & Male & $11012 / 003$ & $05 \mathrm{KYT}$ & $09 / 12 / 2014$ & 15 & 60 & 59 & 60 \\
$\mathbf{0 9 9 1}$ & Female & 0874 & 0881 & $07 / 09 / 2017$ & 16 & 56 & 57 & 50 \\
$\mathbf{0 8 1 2} \boldsymbol{*}$ & Male & 0874 & 0881 & $14 / 08 / 2018$ & 17 & 54 & 57 & 50 \\
\hline
\end{tabular}

*dead; BW: birth weight; HG: heart girth; WH: withers height; BL: body length

Table 2. The performance of inbred calves family at adult years age in BAI Lelede

\begin{tabular}{|c|c|c|c|c|c|c|c|}
\hline \multirow{2}{*}{ Cattle ID } & \multirow{2}{*}{ Sex } & \multirow{2}{*}{$\begin{array}{c}\text { Age } \\
\text { (days) }\end{array}$} & \multicolumn{4}{|c|}{ Adult performances } & \multirow{2}{*}{ Grade } \\
\hline & & & AW (kg) & HG (cm) & WH $(\mathrm{cm})$ & $\mathrm{BL}(\mathrm{cm})$ & \\
\hline 0881 & Female & 805 & 179.5 & 140 & 111 & 106 & II \\
\hline 0874 & Male & 658 & 233 & 150 & 116 & 115 & II \\
\hline 0991 & Female & 809 & 88.5 & 112 & 103 & 99 & - \\
\hline
\end{tabular}

AW: adult weight; HG: heart girth; WH: withers height; BL: body length. ${ }^{*}$ Grading of cattle based on National Standard of Bali cattle (SNI
7651.4:2015) with HG and WH measurements 


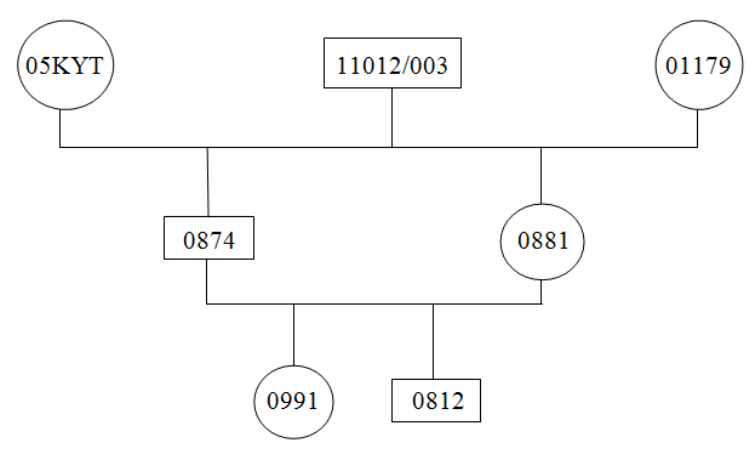

Figure 1. The inbreeding scheme in Bali cattle between two paternal halfsib parental (0874 and 0881) at BAI Lelede. $\square$ : male, $\bigcirc$ : female
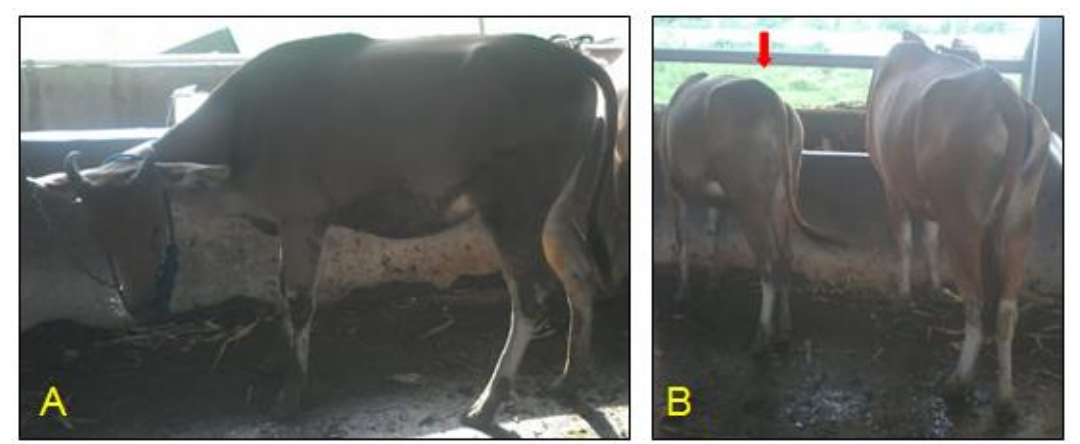

Figure 2. The inbred Bali cow ID: 0991 (A) had small body size (red arrow) compared with the other adult cow (B)

\section{DISCUSSION}

Two calfs of ID: 0812 and ID: 0991 were mentioned as the inbred calves. Thus, both calves were born from inbreeding between two paternal halfsib parents with inbreeding coefficient $\left(\mathrm{F}_{\mathrm{x}}\right)$ value of 0.125 . Sawitri et al. (2012) reported that the $F_{x}$ value in Banteng (Bos indicus) at Surabaya zoo was 0.42 and higher than in this study. The inbred calf ID: 0991 was survived until adult age with lower body weight and body measurements. Barczak et al. (2009) reported that increasing $1 \%$ of inbreeding level in the sheep can be followed by reducing $9.50 \pm 2.30$ gram of birth weight and $11.60 \pm 7.30$ gram of fourth week's weight. Petrovic et al. (2013) reported Mis rams with $F_{x}$ value 0.25 had negative impact to sperm DNA fragmentation level. Meanwhile, Analla et al. (1999) reported that increasing 10\% of inbreeding level in the Merino sheep can be followed by reducing $0.21 \pm 0.01 \mathrm{~kg}$ of birth weight, $0.23 \pm 0.03 \mathrm{~kg}$ of $30 \mathrm{th}$ day's weight, $0.48 \pm 0.04 \mathrm{~kg}$ of 60 th day's weight and $0.82 \pm 0.06 \mathrm{~kg}$ of 90 th day's age. In addition, previous studies reported that the inbreeding in sheep had negative effect on reproductive traits (Selvaggi et al. 2010; Eteqadi et al. 2015), survival rate of lamb (Ceyhan et al. 2011) and body weight (Boujenane and Chami 1997; Mandal et al. 2002; Rzewuska et al. 2005; Norberg and Sorensen 2007). In dairy cattle, the inbreeding was reduced the milk production (Filho et al. 2015), survival rate (Thompson et al. 2000), conception rate (Hofmannova et al. 2019) and fertilization rate of in vitro embryo (Perez et al. 2017).

In the future, the recording and mating management systems in BAI Lelede must be improved to reduce the inbreeding case. Despite, nutrition feed control is important to increase the reproductive traits of cow. The efficiency reproduction can be increased using oestrus synchronization method with artificial insemination. Moreover, the NM system can be improved with bull rotation program. A breeding bull must be used along 2 - 3 years. The breeding bulls used for 3 years in the breeding station and these bulls can be distributed in the villager breeding center $(\mathrm{VBC})$ which very hard to applied AI method. Hence, the inbreeding case can be reduced through bull rotation. The long distance between VBC, AI center or veterinary office can be caused late AI assessment and expensive cost. Furthermore, the inbred cow ID: 0991 can be culled from breeding station because of not in accordance with the Bali cattle breed standard. It can be concluded that level inbreeding 12.5\% in Bali cattle had negative effect of low performance and calf's dead case. 


\section{KAYNAKLAR}

Alvarez G, Quinteiro C, Ceballos FC. Inbreeding and genetic disorder. Adv Study Genet Dis. 2011; 2:21-44.

Analla M, Montilla JM, Serradilla JM. Study of the variability ofthe response to inbreeding for meat production in Merino sheep. J Anim Breed Genet. 1999; 116:481-488.

Barczak E, Wolc A, Wojtowski J, Slosarz P, Szwaczkowski T. Inbreeding and inbreeding depression on body weight in sheep. J Anim Feed Sci. 2009; 18:42-50.

Boujenane I, Chami A. Effects of inbreeding on reproduction, weights and survival of Sardi and Beni Guil sheep. Journal of Animal Breeding and Genetic. 1997; 114:2331.

Ceyhan A, Kaygisiz A, Sezenler T. Effect of inbreeding on preweaning growth traits and survival rate in Sakiz sheep. J Anim Plant Sci. 2011; 21(1):1-4.

Eteqadi B, Hossein-Zadeh NG, Shadparvar AA. Inbreeding effect on reproductive traits in Iranian Guilan sheep. Trop Anim Health Prod. 2015; 47(3):533-539.

Filho JCR, Verneque RS, Torres RA, Lopes PS, Raidan FSS, Toral FLB. Inbreeding on productive and reproductive traits of dairy Gyr cattle. Rev Bras Zootec. 2015; 44(5):174-179

Hofmannova M, Pribyl J, Krupa E, Pesek P. Estimation of inbreeding effect on conception in Czech Holstein. Czech J Anim Sci. 2019; 64(7):309-316.

Julian JOG, Barry WB, David HR, Jonathan DB, David WT, Richard F. Realistic levels of inbreeding depression strongly effect extinction risk in wild populations. Biol Conserv. 2006; 133:42-51.

Kaswati, Sumadi, Ngadiyono N. The heritability estimation of birth weight, weaning weight of Bali cattle at Balai Pembibitan Ternak Unggul Sapi Bali. Bullet Anim Sci. 2013; 37:74-78.

Laws RJ, Jamieson IG. Is lack of evidence of inbreeding depression in a threatened New Zealand robin indicative of reduced genetic load ?. Anim Conserv. 2011; 14:47-55

Mandal AK, Pant KP, Rout PK, Singh SK, Roy R. Influence of inbreeding on growth traits of Muzaffarnagari sheep. Indian J Anim Sci. 2002; 72(11):988-990.

Norberg E, Sorensen AC. Inbreeding trend and inbreeding depression in the Danish, populations of Texel,

Shropshire, and Oxford Down. J Anim Sci. 2007; 85(2):299-304.

Perez BC, Balieiro JCC, Ventura RV, Bruneli VAT. Inbreeding effects on in vitro embryo production traits in Guzera cattle. Animal. 2017; 11(11):1983-1990.

Petrovic VC, Maksimovic N, Petrovic MP, Petrovic MM, Ilic ZZ, Muslic DR. Effect of inbreeding on body growth traits and sperm DNA fragmentation in rams. Anim Sci Pap Rep. 2013; 31(1): 27-33.

Priyanto R, Nuraini H, Muladno, Ismail M, Wijayanto $H$. Slaughter, carcass and non-carcass characteristics of local cattle and buffalo in Indonesia. Pakistan J Nut. 2019; 18:117-124.
Rzewuska K, Klewiec J, Martyniuk E. Effect of inbred on reproduction and body weight of sheep in a closed Booroola flock. Anim Sci Pap Rep. 2005; 23(4):237-247.

Selvaggi M, Dario C, Peretti V, Ciotola F, Canicella D, Dario M. Inbreeding depression in Leccese sheep. Small Rum Res. 2010; 89(1): 42-46.

Sawitri R, Takandjandji M. Inbreeding population of Banteng (Bos javanicus d'Alton 1832) at Surabaya zoo. Bul Plas Nut. 2012; 18:84-94.

Theodorou K., Couvet D. On the expected relationship between inbreeding, fitness and extinction. Genet Sel Evol. 2006; 38:371-387.

Thompson JR, Everett RW, Wolfe CW. Effect of inbreeding on production and survival in Jerseys. J Dairy Sci. 2000; 83(9): 2131-2138.

Wisesa AANGD, Pemayun TGO, Mahardika IGNK. Analisis sekuen D-Loop DNA mitokondria sapi Bali dan Banteng dibandingkan dengan bangsa sapi lain di dunia. Indonesia Med Vet. 2012; 1(2):281-292.

Wulandari A, Nurgiartiningsih VMA, Kuswati, Susilorini TE, Agung PP. Filogeni beberapa sapi lokal Indonesia menggunakan DNA mitokondria COI (Cytochrome Oxidase Sub unit 1). JITPT. 2019; 6(2):278-282. 